\title{
Metafrontier Analysis of Technical Efficiency of Wheat Farms in Sudan
}

\author{
Ali Chebil ${ }^{1}$, Abdelaziz A. Hashim², Alawia Osman Hassan ${ }^{3}$, Ishtiag Abdalla ${ }^{2}$, Izzat Tahir ${ }^{3}$, Solomon Assefa ${ }^{1}$ \& \\ Ouambi Yameogo ${ }^{1}$ \\ ${ }^{1}$ International Center for Agricultural Research in the Dry Areas (ICARDA), Tunis, Tunisia \\ ${ }^{2}$ Agricultural Research Corporation (ARC), Khartoum North, Shambat, Sudan \\ ${ }^{3}$ Agricultural Research Corporation (ARC), Wad Medani, Sudan \\ Correspondence: Ali Chebil, International Center for Agricultural Research in the Dry Areas (ICARDA), Tunis, \\ Tunisia. Tel: 216-71-752-134. E-mail: chebil@yahoo.es
}

Received: October 25, 2015 Accepted: December 7, 2015 Online Published: January 15, 2016

doi:10.5539/jas.v8n2p179 URL: http://dx.doi.org/10.5539/jas.v8n2p179

\begin{abstract}
The major objective of this study is to estimate the technical efficiencies and technological gap of wheat farms in the major wheat producing areas of Sudan, namely Northern, River Nile, Gezira, and Kassala States of Sudan. A total sample of 951 wheat farms was selected and surveyed in the whole country during 2013. Non-parametric Data Envelopment Analysis (DEA) model has been applied to measure the technical efficiency and technological gaps among the regions by means of metafrontier approach. Results show that there is significant inefficiency in wheat farms. The estimated average technical efficiencies with respect to group frontiers for Gezira, Kassala, Northern and River Nile are: $0.52,0.61,0.48$ and 0.41 , respectively. The average technological gap ratios for Gezira, Kassala, Northern and River Nile were $0.82,0.50,0.75$ and 0.92, respectively. Therefore, the Kassala farms frontier has the most distant to the metafrontier, while the Gezira, Northern and River Nile frontiers have the closest. Our results suggest that farms in the Gezira, Northern, and River Nile regions could improve their productivity through more efficient use of inputs using the existing technologies such as sowing, fertilizer application, irrigation water scheduling, and harvesting at the right time. In contrast, improved technologies generation and dissemination such as integrated pest management in the Kassala region are required to improve wheat productivity.
\end{abstract}

Keywords: metafrontier, technical efficiency, Data Envelopment Analysis, wheat farms, regional differences, Sudan

\section{Introduction}

Wheat, sorghum and millet are the most important cereals produced and consumed in Sudan, but wheat becomes the main staple cereal especially in urban areas. It is considered as one of the main food security crops in Sudan, and therefore, the government considered both, production and availability of this commodity as a part of the national security components. The widening gap between domestic production and consumption prompts importation of wheat, which represents heavy burden on scarce public budget resources. There is a continuous deficit between domestic need and local production (Elsheikh et al., 2015). The rapid growth in wheat consumption is mainly due to urbanization, rising incomes, and dietary diversification in recent years which contributed to the increase of the huge deficit in this country. In Sudan, wheat imports account for about $75 \%$ of wheat consumption (FAO, 2014). Production falls short to meet the rising demand leading to increased importation of wheat from international market. Over the past few years there have been sharp global increases in wheat and wheat flour prices resulting in negative impacts on food budgets of most of the poor in rural and urban areas. Despite these domestic market policy incentives for producers, nevertheless, there has been remarkable decrease in cropped area and wheat yields are below the recommended levels thus has pushed wheat imports to triple from 2000 to 2012 (Mustafa et al., 2013). Despite the numerous wheat improved varieties released in the country during the last four decades, wheat productivity is overwhelmingly low as a result of biotic and abiotic stresses, and lack of improved technologies.

Demand for wheat in the Sudan increased over time to the magnitudes that could no longer be satisfied by local 
production. Nevertheless, production of wheat in Sudan can be increased significantly because of the existing natural resources and research knowledge developed over time. Water resources for irrigation are available, offering intensification opportunities to raise productivity, and increase income and food security. The increment in wheat consumption and the high annual growth in wheat imports insist the government to encourage farmers to cultivate more of wheat (Siddig \& Mubarak, 2012). The main contribution mainly came from the irrigation schemes that led and assisted by government staff (Elbashir et al., 2004). Wheat is mainly grown by small producers and efforts to improve its productivity and encouraging policies through prices incentives would guarantee remunerative income that contribute to improving the livelihoods of rural farmers. About $85 \%$ of the wheat area in Sudan is found in the central irrigated plains $\left(14-16^{\circ} \mathrm{N}\right)$.

In this context, using the metafrontier approach is more effective when we wish to compare relative technical efficiency levels across regions and assess the potential to increase wheat by regions. In fact, the advantage of metafrontier is theoretically attractive because it is based on the simple hypothesis that all producers in different regions have potential access to the same technology (Battese et al., 2004; O'donnell et al., 2008). This approach is widely used in agriculture (Okuruwa \& Ogundele, 2004; Neymeck \& Nkamleu, 2006; Villano et al., 2010; Awotide et al., 2015). In case of wheat, only few studies were done (Earfan Ali \& Sama, 2013; Sabouhi \& Esfanjari, 2014). However, to our knowledge, no study has been conducted in Sudan using this approach in the agriculture sector. The major objective of this study is to estimate the technical efficiencies and technological gaps of wheat farms in four regions of Sudan using metafrontier DEA approach. It enables the computation of comparable technical efficiencies for farms operating under different technologies. The model also enables the technology gaps to be estimated for wheat farms under different technologies relative to the potential technology available to the farms.

In this study, we follow the non-parametric Data Envelopment Analysis (DEA) approach to measure inefficiency. DEA has several advantages: it does not require a prior specification of the functional form of the production function and distributional assumption of the inefficiency term. Furthermore, it can handle multiple outputs and inputs with each being stated in different units of measurement, and it generates a set of "peer" units with which a unit is compared (Coelli et al., 2015).

The structure of the paper is as follows. In the next section the wheat sector in Sudan is described. In section 3 the DEA approach to Metafrontier and data used in the study are introduced and explained. Fourth section discusses the results of our study. In the final section of the paper, the main conclusions are summarized.

\section{Overview of Wheat Sector in Sudan}

Wheat is one of the major cereals crop produced and consumed in Sudan and ranked third after sorghum and millet in terms of production. Wheat crop is grown mainly under irrigation production systems in different locations particularly; Northern, Kassala, Gezira, and River Nile States. About $90 \%$ of the wheat area in Sudan is found in these States. The Gezira scheme was the main contributor to wheat production with a share of about $60 \%$ to total production (Ministry of Agriculture and Forests, 2013).

The wheat area, production and yield during 2000-2012 in Sudan are presented in Table 1. Wheat area and production has shown clear fluctuation, and this could be attributed to factors as: government political commitment and support; crop prices and producers' expectations; availability and cost of inputs; and weather conditions. The annual average wheat area in Sudan during the period 2000-2013 is about 195.46 thousand hectare. Wheat area showed variation during the last decades. Annual growth rate was about $4.9 \%$ during the same period.

Between 2000 and 2013, the average wheat production per year is estimated to 405.21 thousand tons in Sudan. In general, the wheat production in Sudan was characterized by an annual fluctuation. On the average wheat production has increased in Sudan at the rate of $2.2 \%$ per annum. During this period, the average yield was about 2.1 tons/ha. Regarding to the yield growth, the rate has been $-2.7 \%$. 
Table 1. Wheat area, production and yield in Sudan during 2000-2013

\begin{tabular}{llllll}
\hline & Mean & Max & Min & CV (\%) & Annual growth rate (\%)* \\
\hline Area (1000 ha) & 195.46 & 400.00 & 91.98 & 42.68 & 4.9 \\
Yield (t/ha) & 2.11 & 2.82 & 1,59 & 17.78 & -2.7 \\
Production (1000 t) & 405.21 & 803.00 & 214.00 & 41.33 & 2.2 \\
\hline
\end{tabular}

Note. *Annual growth rates are estimated by a log-linear regression.

Source: FAO Statistics Division.

The Sudan wheat situation is characterized by rapid growth in consumption, continuous and variable deficit between domestic need and local production. Wheat consumption is increasing at a higher rate than production since 1980s (Mustafa et al., 2013). Per capita wheat consumption has increased from $10 \mathrm{~kg}$ in 1970 to about 63 $\mathrm{kg}$ in 2012 (FAOSTAT). This increase is due mainly to change in the dietary patterns and urbanization since 1980's. The government started to satisfy this increasing demand through imports which showed positive change in most of the years mainly since 1998 (Mustafa et al., 2013). Annual average import is estimated at, 1177 thousand tons in Sudan during the period 2000-2013. On the average wheat imports has increased in Sudan at the rate of $10.7 \%$ per annum during the period 1998-2012. This increase is due mainly to the low rate of wheat productivity growth and the increase of the wheat consumption as a result to the population growth, change in the dietary patterns and urbanization.

Therefore, the share of the domestic production in total consumption is varied along decades since 1980s and that confirmed by Mustafa et al. (2013). The authors compared three decades, 1980-89, 1990-99, and 2000-09. They indicated that the self-sufficiency rate was higher during $1990-99,49 \%$, in comparison to 24 and $25 \%$ for 1980-89 and 2000-09, respectively.

The increment in wheat consumption and the high annual growth in wheat imports entail the government to encourage farmers to cultivate more of wheat to secure the strategic goal (Siddig \& Mubarak, 2012). In this context, the enhancement of wheat productivity in the country is needed. Wheat yield at farmer's field is far behind research yield (Abdalla \& Elhadi, 2011). Ijaimi (2009) indicated the possibility to improve wheat yield and production through improved wheat varieties and technologies.

\section{Methodology}

\subsection{DEA}

Technical efficiency refers to the availability of a firm to produce maximum possible output from a given set of inputs under certain production technology. The efficiency is given by the distance from the observed position of the firm, or more commonly, of the Decision Making Unit (DMU), to its production frontier considered as a benchmark to reach (Farrell, 1957).

DEA is a mathematical linear programming technique developed by Charnes, Cooper, and Rhodes (CCR) in 1978 which identifies the efficient frontier from the linear combination of those units/observations. The CCR model assumes constant returns to scale (CRS). Banker, Charnes, and Cooper (1984) (or BCC model) include an additional convexity constraint to allow for variable returns to scale (VRS). In this study we choose VRS because in agricultural production increasing the inputs does not usually result in a proportional increase in output (Coelli, 1995; Speelman et al., 2008).

Assuming that there are $\mathrm{n}$ DMUs, each producing single output by using $\mathrm{m}$ different inputs and the $i^{\text {th }}$ DMU produces $\mathrm{y}_{\mathrm{i}}$ units of output using $\mathrm{x}_{\mathrm{ki}}$ units of the $k^{\text {th }}$ inputs, the technical efficiency measure is obtained by solving the following linear program for each DMU in the sample (Banker et al., 1984):

$$
\begin{array}{ll}
\text { Subject to: } & \sum_{j=1}^{n} \lambda_{j} y_{j} \geq \theta_{i} y_{i} \\
& \sum_{j=1}^{n} \lambda_{j} x_{k j} \leq x_{k i} \\
& \sum_{j=1}^{n} \lambda_{j}=1 \\
& \lambda_{j} \geq 0
\end{array}
$$

Where, $K=1, \ldots \mathrm{m}$ inputs; $j=1, \ldots \mathrm{n}$ DMUs; $\lambda_{j}$ is the weight of the $j^{\text {th }}$ DMU which provides information on the 
peers of the $i^{\text {th }}$ unit; and $\theta_{i}$ provides information on the technical efficiency score of the $i^{\text {th }}$ unit. $1 \leq \theta_{i}<\infty$ and $\theta_{i}-1$ is the proportional increase in outputs that could be achieved by the $i^{\text {th }}$ DMU, with input quantities held constant. $1 / \theta_{i}$ denotes a technical efficiency score which varies between zero and one. If $\theta_{i}=1$ then the farm is said to be technically efficient. First and second constraints of the Equation 1 generate a set of "peer" units with which a DMU unit is compared (level of frontier as a benchmark to reach). The VRS case is defined by the third constraint $\left(\sum_{j=1}^{n} \lambda_{j}=1\right)$.

The frontier level of production for the $i^{\text {th }}$ DMU, denoted by $y_{i}^{*}$, is given by $y_{i}^{*}=\sum_{j=1}^{n} \lambda_{i} y_{j}=\theta_{i} y_{i}$.

The output-oriented measure of technical efficiency of the $i^{\text {th }} \mathrm{DMU}$, denoted by $\mathrm{TE}_{\mathrm{i}}$, can be calculated as:

$$
T E_{i}=y_{i} / y_{i}^{*}=1 / \theta_{i}
$$

\subsection{DEA Approach to Metafrontier}

DEA allows to estimate the production frontier for a group of firms with similar production technology sets. O'Donnell et al. (2007) argued that the DEA method might sometimes lead to inaccurate results if the sample under consideration includes firms which belong to different environmental characteristics. This is because the efficiency frontiers for these firms might not be identical to provide an unbiased comparison. Hence, these firms should not be treated as one homogenous group. To address this heterogeneity problem, and obtain comparable technical efficiencies for the regions in our sample, we follow the meta-frontier approach (Hayani \& Ruttan, 1971; Lansink et al., 2002; Battese et al., 2004; O'Donnell et al., 2008). Figure 1 shows the relationship among regional frontiers (11', 22', and 33' curves of three regions), metafrontier (MM' curve) and technological gap ratios. As a result, the technical efficiencies regarding to the Metafrontier are the creation of the technical efficiency in respect to the regional frontier and the technological ratio for that region (Rao, et al., 2003).

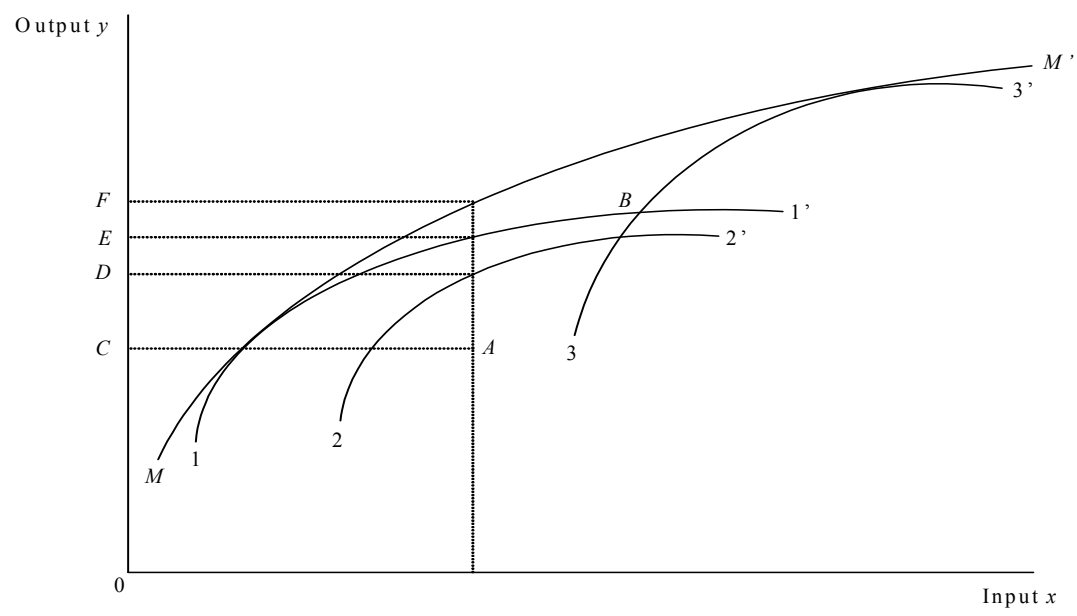

Figure 1. Technical efficiencies and Metatechnology ratios

The DEA metafrontier works to assess efficiencies of firms in different regions that operate under different technologies. This is a threshold concept for measuring the inter-regional efficiency differences. To apply the metafrontier approach with DEA, it is necessary to solve separate models (Equation 1) for each region in order to specify the country-specific frontiers and one for the joint data set for solving the metafrontier. When the metafrontier envelops all group production frontiers, the efficiency can be decomposed into two components (Metafrontier efficiency TE* and region frontier efficiency TE) and the ratio of these two can be called as meta-technology ratio or technological gap ratios (TGR). Using the output orientation, the TGR can be defined as: $\mathrm{TGR}=\mathrm{TE} * \mathrm{TE}$.

The TGR measures the ratio of the output for the frontier production function for the $k^{\text {th }}$ group relative to the potential output that is defined by the metafrontier function, given the observed inputs (Battese \& Rao, 2002; Battese et al., 2004). The TGR has values between zero and one. In the figure above, the technical efficiency of the observation A (inefficient farm because it is below the curve 22') with respect to the technology of region 2 is equal to the ratio OC/OD and with respect to the Metatechnology is OC/OF. Then the TGR for this observation is measured by $\mathrm{OD} / \mathrm{OF}$. 


\subsection{Data}

The data used for this study are obtained from a baseline survey conducted by ICARDA and Agricultural Research Corporation (ARC-Sudan) in 2013 during the implementation of SARD-SC wheat project. A multi-stage sampling procedure was used to select States, villages, and farm households. In the first stage, the baseline survey was targeting the main four wheat producing States in Sudan; namely Northern, River Nile, Kassala, and Gezira. Then, 64 villages from these States were randomly selected. Finally, the total number of the sampled farmers randomly selected was 951, of which 306 farmers were selected from the Northern State, 201 in the River Nile, 161 in Kassala, 283 in Gezira state. The data used in the empirical analysis in this study consisted of a sample of 435 wheat farms after eliminating the outliers and missing data.

Data were collected by trained enumerators from sample households using structured interview schedule. Data were collected through the use of structured questionnaires. The survey collected valuable information on several factors including households composition and characteristics, land and non-land farm assets, households membership in different rural institutions, crop acreage, cost of production, yield data, and indicators of access to infrastructure and households market participation.

One output and four inputs were used in the empirical analysis. Wheat yield per as an area (ton/ha) is used as an output. The labor input consists of labor total cost, measured in (SDG/ha). Farm machinery represents tractor hours (cost) used in production from land preparation through harvest (SDG/ha). Fertilizers represent total costs of chemical cost (SDG/ha). Seed is expressed as the amount used in production $(\mathrm{kg} / \mathrm{ha})$.

The summary statistics of the variables gathered from the farms are reported in Table 2. The standards deviation of the average output indicates the large variability of output among the farms. As it is seen from this table, large variations exist in inputs and output. Such a great variation in input use level may be an indication of a mismanagement problem.

Table 2. Summary statistics for data on wheat farms in Sudan

\begin{tabular}{|c|c|c|c|c|}
\hline & Gezira & Kassala & Northern & River Nile \\
\hline \multicolumn{5}{|c|}{ Output (Ton/ha)) } \\
\hline Mean & 2.2 & 1.4 & 2.5 & 2.5 \\
\hline Min & 0.5 & 0.2 & 0.3 & 0.3 \\
\hline Max & 4.7 & 5.4 & 8.5 & 7.3 \\
\hline SD & 0.8 & 0.8 & 1.5 & 1.5 \\
\hline \multicolumn{5}{|c|}{ Machinery (SDG/ha) } \\
\hline Mean & 343.5 & 438.2 & 924.6 & 735.5 \\
\hline Min & 1.3 & 47.6 & 79.3 & 23.8 \\
\hline Max & 2284.8 & 1751.7 & 5216.2 & 4125.3 \\
\hline SD & 297.1 & 324.7 & 870.8 & 588.7 \\
\hline \multicolumn{5}{|c|}{ Labor (SDG/ha) } \\
\hline Mean & 379.9 & 167.5 & 440.5 & 699.2 \\
\hline Min & 4.8 & 11.9 & 11.9 & 29.8 \\
\hline $\operatorname{Max}$ & 936.9 & 1723.1 & 2558.5 & 4926.6 \\
\hline SD & 260.0 & 269.6 & 495.1 & 823.2 \\
\hline \multicolumn{5}{|c|}{ Seed (Kg/ha) } \\
\hline Mean & 123.0 & 163.0 & 145.3 & 130.4 \\
\hline Min & 7.9 & 119.0 & 41.7 & 4.8 \\
\hline $\operatorname{Max}$ & 492.7 & 495.0 & 428.4 & 386.8 \\
\hline DS & 77.6 & 77.9 & 78.2 & 90.3 \\
\hline \multicolumn{5}{|c|}{ Fertilizer (SDG/ha) } \\
\hline Mean & 997.7 & 790.4 & 899.4 & 875.1 \\
\hline Min & 67.8 & 166.6 & 119.0 & 35.7 \\
\hline $\operatorname{Max}$ & 4117.4 & 2701.3 & 4516.1 & 3141.6 \\
\hline SD & 549.1 & 394.5 & 678.5 & 717.4 \\
\hline
\end{tabular}




\section{Results and Discussion}

Using DEAP software developed by Coelli (1996), a multi-stage DEA model was employed and efficiency scores were estimated under VRS output-oriented given by Equation 1.

The results of technical efficiency from regional frontier (TE), metafrontier (TE*) and technology gap ratio (TGR) estimates for groups are summarized in Table 3. Results show that there are substantial production inefficiencies among wheat farmers. The estimated average technical efficiencies with respect to group frontiers for Gezira, Kassala, Northern and River Nile are: $0.52,0.61,0.48$ and 0.41 , respectively.

The average technological gap ratios for Gezira, Kassala, Northern and River Nile were 0.82, 0.50, 0.75 and 0.92, respectively. Therefore, the Kassala farms frontier has the most distant to the metafrontier, while the Gezira, Northern and River Nile frontiers have the closest. Our results suggest that farms in the Gezira, Northern, and River Nile regions could improve their productivity through more efficient use of inputs using the existing technologies such as sowing, fertilizer application, irrigation water scheduling, and harvesting at the right time. In contrast, improved technologies generation and dissemination such as integrated pest management in the Kassala region are required to improve wheat productivity.

Table 3. Regional technical efficiency and technological Gaps ratios of different regions in Sudan

\begin{tabular}{lllll}
\hline & Gezira & Kassala & Northern & River Nile \\
\hline Regional TE & & & & \\
Mean & 0.52 & 0.61 & 0.48 & 0.41 \\
Min & 0.12 & 0.20 & 0.1 & 0.07 \\
Max & 1 & 1 & 1 & 1 \\
SD & 0.25 & 0.25 & 0.25 & 0.27 \\
Metafrontier TE* & & & & \\
Mean & 0.43 & 0.31 & 0.37 & 0.38 \\
Min & 0.10 & 0.06 & 0.08 & 0.07 \\
Max & 1 & 0.72 & 1 & 1 \\
SD & 0.24 & 0.19 & 0.22 & 0.26 \\
Technology Gap ratio & & & & \\
Mean & 0.82 & 0.50 & 0.75 & 0.92 \\
Min & 0.39 & 0.17 & 0.37 & 0.54 \\
Max & 1 & 0.72 & 1 & 1 \\
SD & 0.16 & 0.18 & 0.15 & 0.12 \\
\hline
\end{tabular}

\section{Conclusion}

The present study focused on a metafrontier analysis of wheat farms in four different regions of Sudan using data of 951 wheat farms from a survey in the whole country during 2013. Non-parametric Data Envelopment Analysis method has applied to assess the technical efficiency and metatechnology ratios in wheat production for four different regions in Sudan. Evidence from the study revealed that there is significant inefficiency in wheat farms. The estimated average technical efficiencies with respect to group frontiers for Gezira, Kassala, Northern and River Nile are: $0.52,0.61,0.48$ and 0.41 , respectively. The average technological gap ratios for Gezira, Kassala, Northern and River Nile were $0.82,0.50,0.75$ and 0.92 , respectively. Therefore, the Kassala farms frontier has the most distant to the metafrontier, while the Gezira, Northern and River Nile frontiers have the closest. Our results suggest that farms in the Gezira, Northern, and River Nile regions could improve their productivity through more efficient use of inputs using the existing technologies such as sowing, fertilizer application, irrigation water scheduling, and harvesting at the right time. In contrast, improved technologies generation and dissemination such as integrated pest management in the Kassala region are required to improve wheat productivity.

Production of wheat in Sudan can be increased significantly on account of the existing natural resources and research knowledge developed over time. Considering the importance of wheat in poverty reduction and food security, there is a need for appropriate policies directed towards enhancing efficiency. Such policies include 
provision of formal credit and strengthening advisory services and technology transfer activities, together with improving infrastructure and marketing facilities could impart better technology development and innovative impact on the livelihood of the farmers.

\section{Acknowledgements}

This work was done within the African Development Bank (AfDB) - funded SARD-SC wheat project. This project is implemented by ICARDA. The authors would like to thank the AfDB for funding this project and the ARC-ICARDA teams for providing the data set to undertake this study.

\section{References}

Abdalla, S., \& Elhadi, H. (2011). Enhancing production technological package to reduce the yield gap of crops between research and farmers. In W. Doppler \& S. Bauer (Eds.), Issues and challenges in Rural development: Compendium of approaches for socio-economic and ecological development in developing countries (Vol. 3). Magraf Publishers, Germany.

Awotide, D. O., Kehinde, A. L., Akorede, T. O., et al. (2015). Metafrontier Analysis of Access to Credit and Technical Efficiency among Smallholder Cocoa Farmers in Southwest Nigeria. International Business Research, 8(1), 132-144. http://dx.doi.org/10.5539/ibr.v8n1p132

Banker, R. D., Charnes, A., \& Cooper, W. W. (1984). Some Models for Estimating Technical and Scale Efficiencies in Data Envelopment Analysis. Management Science, 30, 1078-1092. http://dx.doi.org/10.1287/mnsc.30.9.1078

Battese, G. E. (1997). A notes on the estimation of cobb-douglas production functions when some explanatory variables have zero values. Journal of Agricultural Economics, 48(1-3), 250-252. http://dx.doi.org/10.1111/j.1477-9552.1997.tb01149.x

Battese, G. E., \& Rao, D. S. P. (2002). Technology gap, efficiency and stochastic metafrontier function. International Journal of Business and Economics, 1(2), 1-7.

Battese, G. E., Rao, D. S. P., \& O’Donnell, C. J. (2004). A Metafrontier Production Function for Estimation of Technical Efficiencies and Technology Gaps for Firms Operating Under Different Technologies. Journal of Productivity Analysis, 21(1), 99-103. http://dx.doi.org/10.1023/B:PROD.0000012454.06094.29

Charnes, A., Cooper, W. W., \& Rhodes, E. (1978). Measuring the Efficiency of Decision Making Units. European Journal of Operation Research, 2, 429-444. http://dx.doi.org/10.1016/0377-2217(78)90138-8

Coelli T. (1996). A Guide to DEAP Version 2.1: A Data Envelopment Analysis (Computer) Program. CEPA Working Paper 96/08. Department of Econometrics, University of NewEngland, Armidale, Australia.

Coelli, T. J. (1995). Recent Developments in Frontier Modeling and Efficiency Measurement. Australian Journal of Agricultural Economics, 39(3), 219-245. http://dx.doi.org/10.1111/j.1467-8489.1995.tb00552.x

Coelli, T. J., Rao, D. S. P., O'Donnell, C. J. \& Battese, G. E. (2005). An Introduction to Efficiency and Productivity Analysis. Second ed. New York: Springer.

Earfan Ali, K. M., \& Sama, Q. A. (2013). A metafrontier production function for estimation of technical efficiencies of wheat farmers under different technologies. Journal of Asian Scientific Research, 3(9), 933-944.

Elbashir, A., Siddig F. A., Ijaimi, A., \& Nour, H. M. (2004). Sudan poverty reduction and programs in Agriculture. Report Prepared for the Food and Agriculture Organization (FAO) in Khartoum.

Elsheikh, O. E., Elbushra, A. A., \& Salih, A. A. (2015). Economic impacts of changes in wheat's import tariff on the Sudanese economy. Journal of the Saudi Society of Agricultural Sciences, 14, 68-75. http://dx.doi.org/10.1016/j.jssas.2013.08.002

FAOSTAT. (2014). Food supply, crops primary equivalent. FAO Statistics Division. Retrieved January 3, 2014, from http://faostat.fao.org/site/609/DesktopDefault.aspx?PageID=609\#ancor

Farrell, M. J. (1957). The measurement of productive efficiency. Journal of the Royal Statistical Society, 120(3), 253-290. http://dx.doi.org/10.2307/2343100

Hayami, Y., \& Ruttan, V. W. (1971). Agricultural development: An international perspective Baltimore. Jons Hopkins University Press.

Ijaimi, A. A. M. (2009). Wheat production and processing in Sudan: Strategic view to support national security. Sudan Currency and Printing Press. 
Mahir, M. E. A., \& Abdelaziz, H. H. (2011). Analysis of agricultural production instability in the Gezira scheme. Journal of the Saudi Society of Agricultural Sciences, 10, 53-58. http://dx.doi.org/10.1016/j.jssas.2011.03.008

Ministry of Agriculture and Forests. (2013). Time series of area planted, harvested \& yield data of the main food $\&$ oil crops by states and mode of irrigation (1970/1971-2012/2013). Ministry of Agriculture and Forests, Khartoum, Sudan.

Mustafa, R. H., El Gali, M. B., \& Abulgasim, S. (2013). Trends in wheat production and consumption in Sudan. International Journal of Research in Management, Economics and Commerce, 3(4), 44-56.

Nyemeck, J. B., \& Nkamleu, G. B. (2006). Potentiel de productivité et efficience technique du secteur agricole en Afrique. Canadian Journal of Agricultural Economics, 54, 361-377. http://dx.doi.org/10.1111/j.1744-7976.2006.00055.x

O’Donnel, C. J., Rao, D. S. P., \& Battese, G. E. (2008) Metafrontier Frameworks for the study of firm level efficiencies and technology ratios. Empirical Economics, 34, 231-255. http://dx.doi.org/10.1007/s00181-007-0119-4

Okuruwa, V. O., \& Ogundele, O. O. (2004). Technical efficiency differentials in rice production technologies in Nigeria. Research paper $n^{\circ} 154$, African Economic Research Consortium, Nairobi, Kenya.

Rao, D. S. P., O'donnell, C. J., \& Battese, G. E. (2003). Metafrontier Functions for the Study of Inter-regional Productivity Differences. CEPA Working Papers series $\mathrm{n}^{\circ} 1 / 2003$, School of Economics, University of Queensland, Australia.

Sabouhi, S. M., \& Esfanjari, K. R. (2014). Measuring technological gap ratio of wheat production using StoNED approach to metafrontier. International Journal of Applied Operational Research, 4(2), 33-42.

Siddig, K. H. A., \& Mubarak, A. M. (2013). Food self-sufficiency versus foreign currency earnings in the Sudanese irrigated agriculture. Journal of the Saudi Society of Agricultural Sciences, 12, 19-25. http://dx.doi.org/10.1016/j.jssas.2012.05.001

Speelman, S., D’Haese, M., Buysse, J., \& D’Haese, L. (2008). A measure for the efficiency of water use and its determinants, a case study of small-scale irrigation schemes in North-West province, South Africa. Agricultural Systems, 98, 31-39. http://dx.doi.org/10.1016/j.agsy.2008.03.006

Villano, R., Mehrabi Boshrabadi, H., \& Fleming, E. (2010). When is metafrontier analysis appropriate? An example of varietal differences in pistachio production in Iran. J. Agr. Sci. Tech., 12, 379-389.

\section{Copyrights}

Copyright for this article is retained by the author(s), with first publication rights granted to the journal.

This is an open-access article distributed under the terms and conditions of the Creative Commons Attribution license (http://creativecommons.org/licenses/by/3.0/). 